\title{
Trace elements in dialysis
}

\author{
Guido Filler • Sarah Felder
}

Received: 3 February 2013 /Revised: 1 July 2013 / Accepted: 22 July 2013 /Published online: 16 August 2013

(C) IPNA 2013

\begin{abstract}
In end-stage chronic kidney disease (CKD), pediatric nephrologists must consider the homeostasis of the multiple water-soluble ions that are influenced by renal replacement therapy (RRT). While certain ions such as potassium and calcium are closely monitored, little is known about the handling of trace elements in pediatric dialysis. RRT may lead to accumulation of toxic trace elements, either due to insufficient elimination or due to contamination, or to excessive removal of essential trace elements. However, trace elements are not routinely monitored in dialysis patients and no mechanism for these deficits or toxicities has been established. This review summarizes the handling of trace elements, with particular attention to pediatric data. The best data describe lead and indicate that there is a higher prevalence of elevated lead $(\mathrm{Pb}$, atomic number 82) levels in children on RRT when compared to adults. Lead is particularly toxic in neurodevelopment and lead levels should therefore be monitored. Monitoring of zinc ( $\mathrm{Zn}$, atomic number 30) and selenium (Se, atomic number 34) may be indicated in the monitoring of all pediatric dialysis patients to reduce morbidity from deficiency. Prospective studies evaluating the impact of abnormal trace elements and the possible therapeutic value of intervention are required.
\end{abstract}

G. Filler $(\bowtie) \cdot$ S. Felder

Department of Paediatrics, Division of Nephrology, Children's Hospital, London Health Science Centre, University of Western Ontario, 800 Commissioners Road East, London, ON, Canada N6A 5W9

e-mail: guido.filler@lhsc.on.ca

G. Filler

Department of Medicine, Children's Hospital, London Health Science Centre, University of Western Ontario, London, Canada

\section{G. Filler}

Department of Pathology \& Laboratory Medicine, Children's Hospital, London Health Science Centre, University of Western Ontario, London, Canada
Keywords Zinc $\cdot$ Lead $\cdot$ Manganese $\cdot$ Selenium $\cdot$ Mercury $\cdot$ Chronic kidney disease $\cdot$ Hemodialysis

\section{Introduction}

Dialysis removes uremic toxins by allowing the equilibration of plasma water and dialysate across a semi-permeable membrane. Dialysate is created by adding regulated quantitates of essential ions such as sodium, potassium, bicarbonate, calcium, and magnesium to water that has been treated to reduce solutes to very low levels. The concentration of the biologically essential ions can be matched to those of the patient to equilibrate to a desired plasma concentration. On the other hand, a patient's plasma water can be altered as substances that have lower concentrations in the dialysate than in plasma water will be removed from plasma. This concept is essential for the removal of the nitrogenous waste products that form uremic toxins. Theoretically, dialysis could lead to depletion of biologically essential substances if they are not included in the dialysate. For example, removal of water-soluble vitamins is well known and all dialysis patients are given supplements to replace dialysis losses [1]. While data are available regarding vitamins in chronic kidney disease (CKD), little is known about the trace elements, especially in children. There clearly is potential for deficiencies of trace elements.

At the same time, dialysis patients, especially those on hemodialysis, are exposed to very high volumes ( $>3001$ per week) of dialysate. Therefore, even minute levels of toxic substances in source water could lead to tiny concentration gradients between plasma water and dialysate, potentially leading to clinically relevant toxicity. There are some fundamental differences in the situation in hemodialysis patients, compared to continuous ambulatory peritoneal dialysis (CAPD) patients and patients with CKD not yet on dialysis. Compared to hemodialysis patients, CAPD patients are exposed to much lower dialysate volumes, while CKD patients may have increased proteinuria 
by which there may be an excessive loss of protein-bound trace elements. Aluminum toxicity is a historical example of toxic accumulation in dialysis patients, which occurred due to the common use of aluminum-containing phosphate binders [2] and also due to the use of highly contaminated dialysis fluids [3]. Even today, when aluminum-containing phosphate binders are no longer in use, accidental acute accumulation should still be considered and routine monitoring of aluminum may still be indicated. Taken together, dialysis patients are at theoretical risk for both deficiency and accumulation of trace elements depending upon dietary intake, removal by dialysis, the composition of the source water used for dialysate, and residual renal function. Tonelli et al. [4] published a comprehensive review about the trace element status of adult hemodialysis patients. However, the pediatric literature on this topic remains scare and mostly focuses on lead [5]. The purpose of the current review is to describe the relevance of trace element monitoring in children and adolescents on renal replacement therapy.

\section{What are trace elements?}

Trace elements are known substances that are present in very low concentrations in biological fluids or tissues. These include heavy metals such as cadmium ( $\mathrm{Cd}$, atomic number 48$)$, chromium ( $\mathrm{Cr}$, atomic number 24$)$, nickel $(\mathrm{Ni}$, atomic number 28$)$, vanadium $(\mathrm{V}$, atomic number 23$)$, copper $(\mathrm{Cu}$, atomic number 29), lead $(\mathrm{Pb}$, atomic number 82$)$, manganese $(\mathrm{Mn}$, atomic number 25), selenium (Se, atomic number 34$)$, and zinc ( $\mathrm{Zn}$, atomic number 30 ). In adults, cadmium, chromium, nickel, and vanadium probably do accumulate in hemodialysis patients, but the jury is still out as to whether copper and lead may accumulate. Manganese, selenium, and zinc are probably deficient [4]. Normal plasma concentrations for children and adults of these nine trace elements are given in Table 1. In general, most trace elements show some age dependency, but the subject is understudied in children. It should be noted that many of the papers with reference intervals actually are quite old and more modern methods with mass spectrometry will provide much lower and likely more accurate levels [5]. It is noteworthy that urinary excretion is an important tool for elimination, and urinary concentrations are lower in children with CKD [5].

\section{Toxic trace elements without biological function}

Cadmium has no known biological role in higher organisms [6]. However, low-level exposure to cadmium may increase the risk of CKD, albuminuria, and proteinuria and can therefore be toxic [7]. Chromium exists as a trivalent and hexavalent form. The trivalent form appears to be benign [8], but the hexavalent form is carcinogenic and may cause allergic contact dermatitis [9]. Nickel is best known for causing an allergic contact dermatitis [10], but is also known for causing fume- and dustmediated carcinogenesis [11]. Vanadium plays a limited role in human biology. Vanadium accumulation is considered toxic and exposure is likely to cause permanent health problems or death [12]. Lead interferes with a variety of physiologic processes and is toxic to many organs including the cardiovascular, skeletal, gastrointestinal, reproductive, and nervous systems. In particular, lead inhibits proper neurodevelopment in children and may cause permanent learning and behavior disorders. Acute lead toxicity causes abdominal pain, confusion, headache, anemia, irritability, and, in severe cases, seizures, coma, and death [13]. Manganese, zinc, copper, and selenium are essential trace elements, but the possibility for toxicity with accumulation also exists.

\section{Essential trace elements}

Copper is an essential trace element in plants and animals. Copper proteins have diverse roles in biological electron transport and oxygen transportation. Copper deficiency can cause anemia and neutropenia [14]. Non-protein bound copper ions are toxic by creating reactive oxygen species, which damage biological macromolecules [15]. Manganese is an essential trace element for all life forms. The classes of enzymes that require manganese cofactors are broad. The bestknown manganese-containing polypeptides are arginase and manganese-containing superoxide dismutase [16]. While manganese is much less toxic than other heavy metals, exposure to dust and fumes may cause toxicity and has been linked to impaired motor skills and cognitive disorders [17]. Selenium is also an essential micronutrient. It acts as a cofactor for oxidation and reduction enzymes such as glutathione peroxidase [18]. Zinc is one of the most important micronutrients and deficiency is common worldwide. Failure to thrive, dermatitis, and inflammatory disease are the most common pediatric presentations of zinc deficiency [19]. Zinc is an intrinsic metal and a cofactor for more than 70 enzyme systems, including angiotensin-converting enzyme, alkaline phosphatase, carbonic anhydrase, DNA and RNA polymerases, copper-zinc superoxide dismutase, and metallothionein. Zinc is also the essential constituent of the zinc finger proteins, which are key players in the regulation of gene transcription [20]. CKD patients are at higher risk for zinc deficiency, with up to $78 \%$ of hemodialysis patients being deficient [21].

\section{What are the sources of trace elements?}

Table 2 lists the trace element concentration in various water sources, as well as WHO guidelines. With respect to the individual metals, various environmental compartments are important sources for cadmium, including the atmosphere, land, and 
Table 1 Atomic absorption spectrometry reference intervals (normal range) for cadmium, chromium, nickel, vanadium, copper, lead, manganese, selenium and zing in adults and, if available, in children [54]. *For manganese, the reference intervals are in whole blood [55]. For serum vanadium and for chromium, we could only find old reference intervals with a different method [56]. We also provided the abbreviation and the atomic number as "\#". Adult reference intervals were taken from http://www.amamanualofstyle.com/ page/si-conversion-calculator, accessed 30-Jun-2013

\begin{tabular}{|c|c|c|c|c|c|}
\hline Element & $\begin{array}{l}\text { Adult [with most } \\
\text { commonly used analyte] }\end{array}$ & $\begin{array}{l}\text { Urine } \\
(\mu \mathrm{g} / \text { day })[57]\end{array}$ & $\begin{array}{l}\text { Children serum } \\
(\mu \mathrm{g} / \mathrm{l})[54]\end{array}$ & $\begin{array}{l}\text { Age } \\
\text { dependency }\end{array}$ & $\begin{array}{l}\text { Conversion factor } \\
\text { for SI units }\end{array}$ \\
\hline Cadmium (Cd, \#48) & $\begin{array}{l}0.3-12 \mathrm{ug} / 1 \\
\text { [whole blood] }\end{array}$ & $0.06-0.79$ & $0.5-3.7$ & Yes & $1 \mathrm{ug} / \mathrm{l}=8.929 \mathrm{umol} / 1$ \\
\hline Chromium (Cr, \#24) & $\begin{array}{l}0.7-28.0 \mathrm{ug} / 1^{*} \\
\text { [whole blood] }\end{array}$ & $0.2-2 *$ & & & $1 \mathrm{ug} / \mathrm{l}=19.231 \mathrm{umol} / 1$ \\
\hline Nickel (Ni, \#28) & $\begin{array}{l}1.0-28.0 \mathrm{ug} / 1 \\
\text { [whole blood] }\end{array}$ & $0.59-4.06$ & & & $1 \mathrm{ug} / \mathrm{l}=17.033 \mathrm{nmol} / 1$ \\
\hline Vanadium (V, \#23) & $\begin{array}{l}0.1-1.0 \mathrm{ug} / 1^{*}[57] \\
\text { [plasma] }\end{array}$ & $1.4-10.2$ & & & $1 \mathrm{ug} / \mathrm{l}=19.63 \mathrm{nmol} / 1$ \\
\hline Copper $(\mathrm{Cu}, \# 29)$ & $\begin{array}{l}70-140 \mathrm{ug} / \mathrm{dl} \\
\text { [serum] }\end{array}$ & $4.3-12.1$ & $8.0-29.5$ & Yes & $1 \mathrm{ug} / \mathrm{dl}=0.157 \mathrm{umol} / 1$ \\
\hline Lead $(\mathrm{Pb}, \# 82)$ & $\begin{array}{l}<10 \mathrm{ug} / \mathrm{dl} \\
{[\text { serum] }}\end{array}$ & $0.01-2.14$ & $10-111$ & Yes & $1 \mathrm{ug} / \mathrm{dl}=0.048 \mathrm{umol} / 1$ \\
\hline Manganese (Mn, \#25) & 10-12 ug/1 [whole blood] & $0.11-1.32$ & $5.9-20.9[55]$ & Yes & $1 \mathrm{ug} / \mathrm{l}=18.202 \mathrm{nmol} / 1$ \\
\hline Selenium (Se, \#34) & $58-234 \mathrm{ug} / 1[$ serum $]$ & $10.5-45.5$ & & & $1 \mathrm{ug} / \mathrm{l}=0.0127 \mathrm{umol} / 1$ \\
\hline Zinc (Zn, \#30) & 75-120 ug/dl [serum] & $44-499$ & $25.9-108.8$ & Yes & $1 \mathrm{ug} / \mathrm{dl}=0.153 \mathrm{umol} / 1$ \\
\hline
\end{tabular}

water. The steel industry, waste incineration, and volcanic action are the largest emission sources for air contamination. Waste disposal results in by far the largest cadmium deposition in the land and manufacturers of cadmium-containing products likely account for the most important source of water contamination [22]. Chromium as an environmental pollutant is similarly generated by the commercial applications of various household and industrial materials [9]. Nickel has various sources including its natural distribution in various environmental compartments and its utilization in various industrial and commercial applications. Water and dietary intake constitute the most important intake pathway of nickel, with incidental ingestion of soil and dust being very low in comparison [23]. Vanadium may be a contaminant of ground water due to pollution from industrial waste

Table 2 Trace elements in various water sources. All data except* and ** are from [58]. * is from [59]. ** is from www.hc-sc.gc.ca/ewh-semt/pubs/ water-eau/selenium/index-eng.php\#selenium (accessed 2-Feb-2013)

\begin{tabular}{|c|c|c|c|c|c|}
\hline \multirow{2}{*}{$\begin{array}{l}\text { Trace } \\
\text { element }\end{array}$} & \multirow{2}{*}{$\begin{array}{l}\text { High-purity } \\
\text { water }(\mu \mathrm{g} / \mathrm{l})\end{array}$} & \multicolumn{4}{|c|}{ Bottled water $(\mu \mathrm{g} / \mathrm{l})$} \\
\hline & & Min & Max & Median & $\begin{array}{l}\text { WHO } \\
\text { guidelines }\end{array}$ \\
\hline Cadmium & $0.1 \pm 0.0$ & 0.0006 & 0.265 & 0.008 & 3 \\
\hline Chromium & $0.6 \pm 0.1$ & 0.006 & 1.72 & 0.082 & 50 \\
\hline Nickel* & $<1$ & $<2$ & 69 & & \\
\hline Vanadium & $0.2 \pm 0.0$ & 0.0006 & 93.1 & 0.126 & \\
\hline Copper & $0.7 \pm 0.4$ & 0.025 & 19 & 0.17 & 2000 \\
\hline Lead & $1.8 \pm 0.9$ & $<0.001$ & 0.76 & 0.009 & 10 \\
\hline Manganese & $0.7 \pm 0.3$ & 0.025 & 310 & 0.15 & 400 \\
\hline Selenium** & & & & 0.5 & 10 \\
\hline Zinc & $0.01 \pm 0.01$ & 0.043 & 442 & 0.64 & \\
\hline
\end{tabular}

waters or from natural dissolution from rocks [24]. The best dietary copper sources include seafood, organ meats, whole grains, legumes, and chocolate [25]. Metallic lead rarely occurs in nature and contamination is man-made. Lead paints and lead pencils used to be a major source of contamination. Today, lead may be found in harmful quantities in stoneware, insulation materials, and older houses containing significant lead paint [26, 27]. Public drinking water may still be a considerable exposure source in many areas [27]. Water-borne manganese has a higher bioavailability than dietary manganese [28]. Dietary sources of selenium include nuts, cereals, meat, mushrooms, fish, and eggs [29]. Zinc intake is largely based on the quantity and bioavailability of zinc in food. Red meats, legumes, cereals, and dairy products are the most important dietary sources of zinc in North America, but bioavailability is decreased by some fibers, calcium and ferrous sulfate and folic acid [30]. All of these inhibitors are routinely supplemented in dialysis patients.

\section{How are trace elements absorbed, stored, and excreted?}

Homeostasis is the ability of the body to maintain the content of a specific substance such as a trace element within a certain range despite varying intakes. Homeostasis involves the processes of absorption, storage, and excretion. The relative importance of these three processes varies among the trace elements. The homeostatic regulation of trace elements existing as positively charged ions (cations, for example, copper and zinc) occurs primarily during absorption from the gastrointestinal tract. Trace elements absorbed as negatively charged ions (anions, for example, selenium [31]) are usually absorbed freely and completely from the gastrointestinal tract. Thus, their 
homeostasis is regulated primarily by excretion through the urine, but also through bile, sweat, and even breath. In CKD, urinary excretion is diminished, at least shown for cadmium, lead, and zinc [32]. Importantly, there appears to be an added effect of ions and the degree of ionic valency. In chemistry, valence, also known as valency or valence number, is the number of valence bonds a given atom can form, with one or more other atoms. For most elements, the number of bonds can vary. Zinc is often bivalent and aluminum is trivalent. Ozaki et al. showed an increasing degree of interaction in the increasing order of ionic valency when studying interacting metal elements in ion uptake by carrots [33]. This is presumably the result of the large electric valency that caused cell membrane disintegrity. In humans, these effects are largely understudied.

Storage of trace elements in inactive sites or forms is another mechanism that prevents inappropriate amounts of reactive trace elements to be present. Release of a trace element from a storage site can also be important in preventing deficiency. Hair represents the storage over time; however, studies in dialysis patients remain scarce. Copper is absorbed in the gut and transported in the bloodstream by ceruloplasmin, which binds the majority of serum copper. Bile is the major pathway of excretion. Copper undergoes enterohepatic recirculation and excess can be excreted via the gastrointestinal tract [34].

It should be noted that measurement of serum or plasma levels is not necessarily representative of bodily content, given that many of these elements are bound to intracellular proteins [35]. Distribution of trace elements also varies by organ [36]. For instance, there have been reports about an increase of trace elements during hemodialysis, suggesting compartmentalization of the trace elements [37]. Furthermore, trace elements may accumulate in other tissues, such as liver and bone. Significantly increased tissues concentrations were found for strontium, molybdenum, cadmium, and tin [38]. In that same study of 120 dialysis patients as well as 29 CKD patients without dialysis and 64 control subjects by Smythe WR et al., the distributions of copper and zinc were significantly altered, whereas copper plasma and blood levels may be normal in some studies, suggesting that the most widely available blood levels are not necessarily a marker that reveal all of the changes of trace elements in dialysis patients.

\section{What is the influence of renal replacement therapy on trace elements?}

- Plasma protein binding of trace elements

The binding affinity of the trace elements to serum proteins is very important for removal by conventional hemodialysis and peritoneal dialysis [39]. Studies on the protein binding of trace elements and their behavior during dialysis are scarce. Methods for assessing this is either possible through "in vitro" and "in vivo" studies with radioactive isotopes of the trace elements through recovery [39], or by gamma-ray spectrometry [40]. Sotogaku et al. found that beryllium, vanadium, manganese, and zinc are highly bound to plasma proteins, with vanadium and selenium being highly bound to corpuscles, and selenium to the erythrocyte ghosts as well. Beryllium showed the highest plasma protein binding of $91 \%$, strontium (77\%), manganese (71\%), and vanadium $(65 \%)$, while selenium showed low plasma protein binding (25\%) and zinc only $12-17 \%$, thus more prone to loss through dialysis fluid. Which protein each of the trace elements is mostly bound to is highly variable. Cadmium is highly bound to albumin and transferrin [41]. Zinc is bound to albumin, $\alpha 2$-macroglobulin and transferrin and albumin binding is loose [42].

- The influence of dialysis feed water as a potential source of contamination

No water source is free of trace elements. It was already outlined above that dialysis feed water may be a considerable source of toxic trace elements that can accumulate because of the large exposure especially during hemodialysis [5]. The concentration of the free fraction of the elements in the blood compartment determines to which extent exchange with dialysis fluid takes place. The matter is significantly understudied, and there is a paucity of pediatric data. During hemodialysis sessions in adults, copper actually increased slightly following hemodialysis, as did zinc and lead levels, whereas cadmium remained unchanged, and other trace elements were not measured [37]. It is important when interpreting (small) changes pre-versus post-dialysis in the concentration of trace elements, the dialytic ultrafiltration has to taken into account. We recently demonstrated the importance of this phenomenon with the handling of cystatin C during hemodialysis sessions [43]. In an unpublished study in adults, our group compared lead levels among different forms of dialysis in 50 dialysis patients. The mean age \pm standard deviation (SD) of the patients was $52 \pm 11.1$ years. There were 20 (43\%), 12 (26\%), 5 (11\%), and 9 (20\%) patients who were on short daily, frequent nocturnal, intermittent nocturnal, and intermittent daily hemodialysis, respectively. Frequent nocturnal patients would have the highest feed water exposure. The median blood lead level was $4.4 \mu \mathrm{g} / \mathrm{dl}$ (inter quartile range; $\mathrm{IQR}=3.2,5.6)$, which was significantly different $(p<0.001)$ from normal $(1.5 \mu \mathrm{g} / \mathrm{dl})$ and toxic $(>10-50 \mu \mathrm{g} / \mathrm{dl})$ levels. There were no significant differences in medium blood lead levels between patients who were on different hemodialysis modalities $(p=0.81)$. Lead concentration in dialysate feed water was always $<0.00018 \mathrm{mg} / \mathrm{l}$, which is below the accepted limit for water for dialysis of $0.005 \mathrm{mg} / \mathrm{l}$. A previously published study in adult PD and pediatric dialysis patients also suggested that hemodialysis feed water was not a significant source of lead and we did not find differences between the adult PD patients and the pediatric hemodialysis patients [5]. These data would suggest that 
dialysis feed water was not a significant source of lead. It should be highlighted that adult lead reference intervals are much higher than children.

- Dialysis fluid as a source of excessive loss

While the accumulation of toxic trace elements in pediatric dialysis patients remains understudied, there are similarly few data on losses of essential trace elements during renal replacement therapy. Pasko D. et al. [44] studied a case series of five pediatric patients on continuous renal replacement therapy and demonstrated trans-membrane losses of chromium, copper, manganese, selenium, and zinc. Trace elements were supplemented intravenously, and the supplements exceeded the losses; however, such trace elements are not usually supplemented routinely in outpatient dialysis patients. Tonelli et al. demonstrated in their meta-analysis of 128 eligible studies that levels of selenium, zinc, and manganese were lower in hemodialysis patients, compared with controls [4]. There are data to suggest an association of low selenium levels with hypertension, heart failure, and coronary disease in adults, and a recent study demonstrated an inverse association between selenium levels and the risk of death among adult hemodialysis patients, especially death due to infectious diseases $[45,46]$. However, data on the morbidity associated with low selenium levels in children are elusive. As this is a potentially modifiable deficiency and as children with CKD are at an even greater risk of cardiac morbidity and mortality [47], monitoring of selenium in pediatric dialysis is likely paramount. We found only one study on selenium levels in pediatric hemodialysis patients, which demonstrated decrease hair selenium levels and impaired antioxidative capacity in both peritoneal and hemodialysis patients [48]. Zinc and copper levels were studied by Esfahani et al. in three groups of children: hemodialysis patients, CKD stage IV patients managed conservatively, and healthy children. This study revealed significantly lower zinc levels in the 40 hemodialysis patients as well as an inverse correlation between duration of hemodialysis and serum levels of zinc, while there was no difference between healthy children and CKD stage IV for both copper and zinc levels [49]. Zinc and copper balance was studied in children with continuous ambulatory peritoneal dialysis, and zinc levels declined with duration of dialysis, but could be normalized with supplementation [50]. Interestingly, patients absorbed zinc from peritoneal dialysis, suggesting that decreased intake due to dietary restrictions and uremic anorexia may be causative. The undersigned wonder how many pediatric dialysis centers routinely monitor and supplement zinc in their patients. Given that the urinary zinc excretion is inversely correlated with age, zinc deficiency is an especially important consideration in pediatric dialysis patients [51].

Theoretically, patients with proteinuria could have lower levels of trace element levels for those trace elements that exhibit high plasma protein binding. Cadmium is such a trace element, but there are no studies comparing these levels in patients with and without proteinuria. However, there is evidence for substantially increased risk of kidney stones in patients with chronic cadmium poisoning, and this may be related to the excretion of albumin-bound cadmium [52]. Chia et al. [53] demonstrated that the variability of urinary low molecular weight proteins was highly correlated with the lead exposure over time, suggesting that proteinuria may indeed serve as an accelerated means of lead elimination. Taken together, proteinuria may therefore explain some of the intra-patient variability.

\section{Conclusions}

Heavy metal homeostasis is clearly altered in end-stage renal disease, particularly in patients with hemodialysis. While toxic trace elements tend to accumulate, essential micronutrients such as selenium and zinc appear to be depleted in dialysis patients. The phenomenon worsens with the duration of dialysis. Given the important biological function of these essential elements, especially as antioxidants, monitoring of trace elements should be part of the regular assessment of pediatric dialysis patients regardless of the mode of renal replacement therapy. Zinc and selenium are easily supplemented with significant health implications. Toxic trace elements such as lead tend to be more elevated in pediatric dialysis patients compared to adult dialysis patients and healthy controls. The implications for neurocognitive functioning and anemia management are understudied. The authors conclude that regular assessment of the nine trace elements discussed in this review would be an asset in the management of these patients. Probably, the need for monitoring is not just limited to the nine trace elements discussed here. Monitoring of other essential elements should be considered, for instance for magnesium, strontium, aluminum, and others. For instance, for magnesium, both low and high values have been reported, and the causes are multifactorial, albeit toxic effects of high magnesium levels still need to be evaluated. Further prospective studies linking levels to outcomes in pediatric dialysis patients are needed.

\section{Questions (answers are provided following the reference list)}

1. Which of the following statements is true?

a. Trace elements are known substances that are present in very low concentrations in biological fluids or tissues.

b. Molybdenum is a trace element.

c. Cadmium, chromium, nickel, and vanadium probably accumulate in dialysis patients.

d. In analytical chemistry, a trace element is an element in a sample that has an average concentration of less 
than 100 parts per million measured in atomic count or less than 100 micrograms per gram.

e. All of the above.

2. Which of the following statements is true?

a. Cadmium has an important biological role in higher organisms.

b. The hexavalent form of chromium is benign.

c. Vanadium is very toxic and exposure is likely to cause permanent health problems or death.

d. Chronic lead toxicity causes abdominal pain, confusion, headache, anemia, and irritability.

e. Manganese, zinc, copper, and selenium cannot accumulate in CKD.

3. Which of the following statements is false?

a. Zinc is one of the most important micronutrients and deficiency is common worldwide, potentially causing failure to thrive, dermatitis, and inflammatory disease.

b. Zinc is an intrinsic metal and a cofactor for multiple enzyme systems, including angiotensin converting enzyme, alkaline phosphatase, carbonic anhydrase, DNA and RNA polymerases, copper-zinc superoxide dismutase, and metallothionein.

c. CKD patients are at a low risk for zinc deficiency because of accumulation of zinc due to decreased renal clearance.

d. Zinc levels range between 25.9 and $108.8 \mathrm{ug} / \mathrm{l}$ in healthy children.

e. Zinc has measurable levels in bottled water but its concentration in high purity dialysis water is negligible.

4. Which of the following statements is true?

a. There is no safe lead level for children.

b. Children on dialysis have a higher prevalence of elevated lead levels than adult dialysis patients.

c. Hemodialysis feed water in academic centers is not a significant source of lead.

d. Dialysis fluid does not serve as a source of excessive loss of lead.

e. All of the above.

\section{Conflict of interest None}

Financial disclosure None

\section{References}

1. Wiesen P, Van Overmeire L, Delanaye P, Dubois B, Preiser JC (2011) Nutrition disorders during acute renal failure and renal replacement therapy. J Parenter Enteral Nutr 35:217-222

2. Sedman A (1992) Aluminum toxicity in childhood. Pediatr Nephrol 6:383-393
3. Berend K, van der Voet G, Boer WH (2001) Acute aluminum encephalopathy in a dialysis center caused by a cement mortar water distribution pipe. Kidney Int 59:746-753

4. Tonelli M, Wiebe N, Hemmelgarn B, Klarenbach S, Field C, Manns B, Thadhani R, Gill J (2009) Trace elements in hemodialysis patients: a systematic review and meta-analysis. BMC Med 7:25

5. Filler G, Roach E, Yasin A, Sharma AP, Blake PG, Yang L (2012) High prevalence of elevated lead levels in pediatric dialysis patients. Pediatr Nephrol 27:1551-1556

6. Lane TW, Saito MA, George GN, Pickering IJ, Prince RC, Morel FM (2005) Biochemistry: a cadmium enzyme from a marine diatom. Nature 435:442

7. Ferraro PM, Costanzi S, Naticchia A, Sturniolo A, Gambaro G (2010) Low level exposure to cadmium increases the risk of chronic kidney disease: analysis of the NHANES 1999-2006. BMC Publ Health 10:304

8. Mertz W (1993) Chromium in human nutrition: a review. J Nutr $123: 626-633$

9. Barceloux DG (1999) Chromium. J Toxicol Clin Toxicol 37:173-194

10. Mason J, English JC 3rd (2012) Nickel dermatitis. J Pediatr Adolesc Gynecol 25:410-411

11. Kasprzak KS, Sunderman FW Jr, Salnikow K (2003) Nickel carcinogenesis. Mutat Res 533:67-97

12. Worle-Knirsch JM, Kern K, Schleh C, Adelhelm C, Feldmann C, Krug HF (2007) Nanoparticulate vanadium oxide potentiated vanadium toxicity in human lung cells. Environ Sci Technol 41:331-336

13. Staudinger KC, Roth VS (1998) Occupational lead poisoning. Am Fam Physician 57(719-726):731-712

14. Bonham M, O'Connor JM, Hannigan BM, Strain JJ (2002) The immune system as a physiological indicator of marginal copper status? Br J Nutr 87:393-403

15. Brewer GJ (2010) Copper toxicity in the general population. Clin Neurophysiol 121:459-460

16. Culotta VC, Yang M, O'Halloran TV (2006) Activation of superoxide dismutases: putting the metal to the pedal. Biochim Biophys Acta 1763:747-758

17. Young RJ, Critchley JA, Young KK, Freebairn RC, Reynolds AP, Lolin YI (1996) Fatal acute hepatorenal failure following potassium permanganate ingestion. Hum Exp Toxicol 15:259-261

18. Bodnar M, Konieczka P, Namiesnik J (2012) The properties, functions, and use of selenium compounds in living organisms. J Environ Sci Health C Environ Carcinog Ecotoxicol Rev 30:225-252

19. Bock DE, Prabhakaran V, Filler G (2009) Picture of the month: severe zinc deficiency in infancy (acrodermatitis enteropathica-like picture). Arch Pediatr Adolesc Med 163:765-766

20. King JC (1986) Assessment of techniques for determining human zinc requirements. J Am Diet Assoc 86:1523-1528

21. Roozbeh J, Sharifian M, Sagheb MM, Shabani S, Hamidian Jahromi A, Afshariani R, Pakfetrat M, Salehi O (2011) Comment on: does zinc supplementation affect inflammatory markers in hemodialysis patients? Ren Fail 33:466-467

22. Hutton M (1983) Sources of cadmium in the environment. Ecotoxicol Environ Saf 7:9-24

23. De Brouwere K, Buekers J, Cornelis C, Schlekat CE, Oller AR (2012) Assessment of indirect human exposure to environmental sources of nickel: oral exposure and risk characterization for systemic effects. Sci Total Environ 419:25-36

24. Wright MT, Belitz K (2010) Factors controlling the regional distribution of vanadium in groundwater. Ground Water 48:515-525

25. Sadhra SS, Wheatley AD, Cross HJ (2007) Dietary exposure to copper in the European Union and its assessment for EU regulatory risk assessment. Sci Total Environ 374:223-234

26. Grandjean P (1978) Widening perspectives of lead toxicity. A review of health effects of lead exposure in adults. Environ Res 17:303-321

27. Levin R, Brown MJ, Kashtock ME, Jacobs DE, Whelan EA, Rodman J, Schock MR, Padilla A, Sinks T (2008) Lead exposures 
in U.S. Children, 2008: implications for prevention. Environ Health Perspect 116:1285-1293

28. Bouchard MF, Sauve S, Barbeau B, Legrand M, Brodeur ME, Bouffard T, Limoges E, Bellinger DC, Mergler D (2011) Intellectual impairment in school-age children exposed to manganese from drinking water. Environ Health Perspect 119:138-143

29. Schroeder HA, Frost DV, Balassa JJ (1970) Essential trace metals in man: selenium. J Chronic Dis 23:227-243

30. Maret W, Sandstead HH (2006) Zinc requirements and the risks and benefits of zinc supplementation. J Trace Elem Med Biol 20:3-18

31. Rayman MP (2012) Selenium and human health. Lancet 379:1256-1268

32. Wihelm M, Hanewinckel B, Blaker F (1986) Influence of haemodialysis and renal transplantation on trace element concentrations in children with chronic renal failure. Eur J Pediatr 145:372-376

33. Ozaki T, Ambe S, Minai Y, Enomoto S, Yatagai F, Abe T, Yoshida S, Makide Y (2001) Effects of ionic valency of interacting metal elements in ion uptake by carrot (Daucus carota cv. U.S. harumakigosun). Biol Trace Elem Res 84:197-211

34. Linder MC, Wooten L, Cerveza P, Cotton S, Shulze R, Lomeli N (1998) Copper transport. Am J Clin Nutr 67:965S-971S

35. Hambidge M (2003) Biomarkers of trace mineral intake and status. J Nutr 133(Suppl 3):948S-955S

36. Sandstead HH (1980) Trace elements in uremia and hemodialysis. Am J Clin Nutr 33:1501-1508

37. Krachler M, Prohaska T, Koellensperger G, Rossipal E, Stingeder G (2000) Concentrations of selected trace elements in human milk and in infant formulas determined by magnetic sector field inductively coupled plasma-mass spectrometry. Biol Trace Elem Res 76:97-112

38. Smythe WR, Alfrey AC, Craswell PW, Crouch CA, Ibels LS, Kubo H, Nunnelley LL, Rudolph H (1982) Trace element abnormalities in chronic uremia. Ann Intern Med 96:302-310

39. Borguet F, Cornelis R, Delanghe J, Lambert MC, Lameire N (1995) Study of the chromium binding in plasma of patients on continuous ambulatory peritoneal dialysis. Clin Chim Acta 238:71-84

40. Sotogaku N, Endo K, Hirunuma R, Enomoto S, Ambe S, Ambe F (1999) Binding properties of various metals to blood components and serum proteins: a multitracer study. J Trace Elem Med Biol 13:1-6

41. De Smet H, Blust R, Moens L (2001) Cadmium-binding to transferrin in the plasma of the common carp Cyprinus carpio. Comp Biochem Physiol C Toxicol Pharmacol 128:45-53

42. Fisher GL (1975) Function and homeostasis of copper and zinc in mammals. Sci Total Environ 4:373-412

43. Huang SH, Filler G, Yasin A, Lindsay RM (2011) Cystatin C reduction ratio depends on normalized blood liters processed and fluid removal during hemodialysis. Clin J Am Soc Nephrol 6:319-325

44. Pasko DA, Churchwell MD, Btaiche IF, Jain JC, Mueller BA (2009) Continuous venovenous hemodiafiltration trace element clearance in pediatric patients: a case series. Pediatr Nephrol 24:807-813

45. Fujishima Y, Ohsawa M, Itai K, Kato K, Tanno K, Turin TC, Onoda T, Endo S, Okayama A, Fujioka T (2011) Serum selenium levels are inversely associated with death risk among hemodialysis patients. Nephrol Dial Transplant 26:3331-3338

46. Fujishima Y, Ohsawa M, Itai K, Kato K, Tanno K, Turin TC, Onoda T, Endo S, Okayama A, Fujioka T (2011) Serum selenium levels in hemodialysis patients are significantly lower than those in healthy controls. Blood Purif 32:43-47

47. Filler G (2011) Challenges in pediatric transplantation: the impact of chronic kidney disease and cardiovascular risk factors on long-term outcomes and recommended management strategies. Pediatr Transplant 15:25-31

48. Ortac E, Ozkaya O, Saraymen R, Yildiz N, Bedir A, Buyan N, Bek K, Okuyucu A, Baysal K (2006) Low hair selenium and plasma glutathione peroxidase in children with chronic renal failure. Pediatr Nephrol 21:1739-1745

49. Esfahani ST, Hamidian MR, Madani A, Ataei N, Mohseni P, Roudbari M, Haddadi M (2006) Serum zinc and copper levels in children with chronic renal failure. Pediatr Nephrol 21:1153-1156

50. Tamura T, Vaughn WH, Waldo FB, Kohaut EC (1989) Zinc and copper balance in children on continuous ambulatory peritoneal dialysis. Pediatr Nephrol 3:309-313

51. Berglund M, Lindberg AL, Rahman M, Yunus M, Grander M, Lonnerdal B, Vahter M (2011) Gender and age differences in mixed metal exposure and urinary excretion. Environ Res 111:1271-1279

52. Scott R, Cunningham C, McLelland A, Fell GS, Fitzgerald-Finch OP, McKellar N (1982) The importance of cadmium as a factor in calcified upper urinary tract stone disease-a prospective 7-year study. Br J Urol 54:584-589

53. Chia KS, Jeyaratnam J, Lee J, Tan C, Ong HY, Ong CN, Lee E (1995) Lead-induced nephropathy: relationship between various biological exposure indices and early markers of nephrotoxicity. Am J Ind Med 27:883-895

54. Liu J, Yuan E, Zhang Z, Jia L, Yin Z, Meng X, Du H (2012) Age- and sex-specific reference intervals for blood copper, zinc, calcium, magnesium, iron, lead, and cadmium in infants and children. Clin Biochem 45:416-419

55. Smith EA, Newland P, Bestwick KG, Ahmed N (2013) Increased whole blood manganese concentrations observed in children with iron deficiency anaemia. J Trace Elem Med Biol 27:65-69

56. Iyengar GV (1998) Reevaluation of the trace element content in reference man. Radiat Phys Chem 51:545-560

57. Goulle JP, Mahieu L, Castermant J, Neveu N, Bonneau L, Laine G, Bouige D, Lacroix C (2005) Metal and metalloid multi-elementary ICP-MS validation in whole blood, plasma, urine and hair. Reference values. Forensic Sci Int 153:39-44

58. Krachler M, Shotyk W (2009) Trace and ultratrace metals in bottled waters: survey of sources worldwide and comparison with refillable metal bottles. Sci Total Environ 407:1089-1096

59. Allen HE, Halley-Henderson MA, Hass CN (1989) Chemical composition of bottled mineral water. Arch Environ Health 44:102-116

\section{Answers}
1. E
2. C
3. $\mathrm{C}$
4. E 